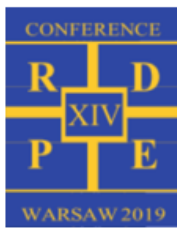

\title{
The analysis of a Velox-type CHP plant for various gaseous fuels
}

\author{
Krystian Smołka ${ }^{1, *}$, and Sławomir Dykas ${ }^{1}$ \\ ${ }^{1}$ Silesian University of Technology, Institute of Power Engineering and T urbomachinery, Konarskiego 18, 44-100 Gliwice, \\ krystian.smolka@polsı.pl, slawomir.dykas@polsl.pl, Poland
}

\begin{abstract}
For many years, the Institute of Power Engineering and Turbomachinery of the Silesian U niversity of Technology has been using a small-capacity (about $500 \mathrm{~kW}$ e) steam-gas power plant. Based on many years of experience in operation of this power plant utilizing the $V$ elox-type gas-steam system, an idea arose to modify this type of thermal power cycle to create a combined heat and power (CHP) plant of small capacity, dedicated for distributed heat and power production of the range up to $500 \mathrm{~kW}$ or production process steam with high temperature. Previous thermodynamic and economic analysis of that type of $\mathrm{CHP}$ plant were conducted for natural gas as a fuel. The new idea is use the alternative gas fuels or waste heat for V elox-type CHP plant. An adaptation of the V elox-type CHP plant for various fuels can be done in simple way by moving the combustion chamber out from the set of heat exchangers, in similar way as it is done for HRSG. This paper presents a thermodynamic analysis of the $V$ elox-type steam-gas cycle fired with various alternative gas fuels such as coke gas, blast furnace gas, biogas or gas from gasification. The systems are modelled in the EBSIL ON ${ }^{\circledR}$ Professional 13 program.
\end{abstract}

\section{Introduction}

Historically, the first idea for combining gas and steam turbine cycles was to install a steam generator in place of the gas turbine combustion chamber. This concept was put forward by the Brown Boveri company, which patented the Velox-type gas-steam system in 1932. In 1939, a gas turbine was used for the first time in the world to produce electricity. It was also the first gassteam system used for electricity generation [1, 2].

Considering the amount of steam generated, the Velox-type steam generator is characterized by a compact structure and relatively small heat transfer surface area, especially in the evaporator. This is due to the fact, that the heat exchange process in the combustion chamber takes place in overpressure, which intensifies the heat transfer between exhaust gases and water and steam in the tubes of the evaporator or steam superheaters. The high velocity of the exhaust gas enabled effective use of the combustion chamber surface area [2]. The implementation of this type of steam generator in power engineering made it possible to create highly efficient plants generating electricity and heat, i.e., the first combined heat and power plant (CHP plant) $[1,3]$.

For many years, the Institute of Power Engineering and Turbomachinery of the Silesian University of Technology has been using a small-capacity (about $500 \mathrm{~kW}$ e) steam-gas power plant of a V elox-type cycle for purposes related to both teaching and experimental testing of steam condensing flows [4]. The experience gained so far from the operation of this power plant based on a $V$ elox-type gas-steam system confirms very good flexibility of the system operation, the short time needed to prepare live steam with required parameters, the parameters stability and the fast rate of load change.

Based on this an idea arose to modify this type of thermal power cycle to create a combined heat and power (CHP) plant of small capacity, dedicated for distributed heat and power production of the range up to $500 \mathrm{~kW}$ or production process steam with high temperature. Previous thermodynamic and economic analysis $[5,6]$ of that type of CHP plant fired with natural gas, and compared with classical gas-steam cycle $[7,8]$ led to conclusions:

- Velox-type plant can operate for much less load than classical CHP plant,

- V elox-type steam-gas unit creates an opportunity to use higher temperatures of live steam,

- Velox-type plant can operate for much less load than classical CHP plant,

- Velox-type plant can be much cheaper than classical CHP plant.

The new idea is use the alternative gas fuels or waste heat for V elox-type CHP plant. An adaptation of V eloxtype CHP plant for various fuels can be done in simple way by moving on combustion chamber out from the set of heat exchangers.

This paper presents a thermodynamic analysis obtained by modelling the Velox-type steam-gas cycle fired with various al ternative gas fuels in the EBSIL ON ${ }^{\circledR}$ Professional 13 program.

The considerations presented herein concern smallcapacity power plant with the power output of the order of a few megawatts of electric power, intended for distributed generation of electricity and heat based on the various gas fuel. 


\section{Thermal power cycle and parameters}

The Velox-type CHP plant (Fig. 1) is characterized by a much higher ratio of electricity obtained from the steam turbine and the gas turbine, respectively, compared to classical gas-steam cycles which are now in use. From the same amount of fuel more steam with higher enthalpy is produced [6]. The Velox-type CHP plant systems was modelled in the EBSILON ${ }^{\circledR}$ Professional 13 program according to technological structure depicted in the Fig. 1.

In Table 1 the basic parameters are presented for nominal load of the Velox-type CHP plant under consideration. It sets out all important parameters for cycle presented above, as well as efficiency of main and auxiliary machines.

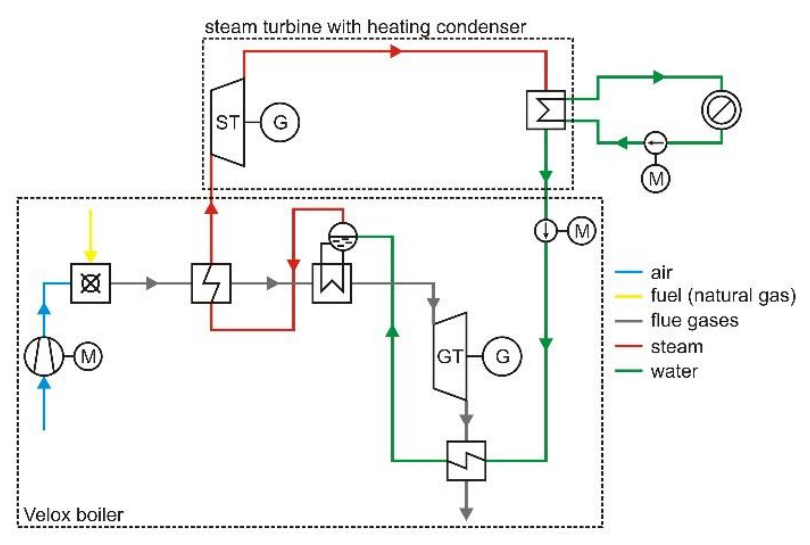

Fig. 1. V elox-type CHP plant scheme.

Table 1. Basic operating parameters for the Velox-type CHP plant under consideration (nominal load).

\begin{tabular}{|c|c|c|}
\hline Parameter & Value & Unit \\
\hline Air pressure upstream the compressor & 0.1 & $\mathrm{MPa}(\mathrm{a})$ \\
\hline Air temperature upstream the compressor & 20 & ${ }^{\circ} \mathrm{C}$ \\
\hline Air mass flow & 0.1 & $\mathrm{~kg} / \mathrm{s}$ \\
\hline Air pressure downstream the compressor & 0.3 & $\mathrm{MPa}(\mathrm{a})$ \\
\hline Fuel pressure upstream the combustion chamber & 0.3 & $\mathrm{MPa}(\mathrm{a})$ \\
\hline Fuel temperature upstream the combustion chamber & 20 & ${ }^{\circ} \mathrm{C}$ \\
\hline Exhaust gas temperature downstream the combustion chamber & 700 & ${ }^{\circ} \mathrm{C}$ \\
\hline Exhaust gas pressure downstream the gas turbine & 0.1 & $\mathrm{MPa}(\mathrm{a})$ \\
\hline Live steam temperature & 680 & ${ }^{\circ} \mathrm{C}$ \\
\hline Live steam pressure & 2 & $\mathrm{MPa}(\mathrm{a})$ \\
\hline Steam temperature downstream of the steam turbine & 265 & ${ }^{\circ} \mathrm{C}$ \\
\hline Steam pressure downstream the steam turbine & 0.1 & $\operatorname{MPa}(\mathrm{a})$ \\
\hline Inlet temperature of the heating water circuit & 30 & ${ }^{\circ} \mathrm{C}$ \\
\hline Outlet temperature of the heating water circuit & 94.6 & ${ }^{\circ} \mathrm{C}$ \\
\hline Gas turbine internal efficiency & 90 & $\%$ \\
\hline Steam turbine internal efficiency & 90 & $\%$ \\
\hline Efficiency of generators & 98.6 & $\%$ \\
\hline Compressor efficiency & 85 & $\%$ \\
\hline Efficiency of pumps & 80 & $\%$ \\
\hline Electric efficiency of motors driving the pumps and compressor & 95 & $\%$ \\
\hline Mechanical efficiency of motors (for pumps and compressor) & 99.8 & $\%$ \\
\hline
\end{tabular}

\section{Considered gas fuels}

Four types of alternative gas fuels, already successfully used in the production of electricity and heat, were selected for the analysis of the Velox-type CHP plant work. These are biogas, blast furnace gas, coke gas and syngas from coal gasification. In addition, two different syngases obtained from the most popular gasification processes were selected to analyse the Velox-type CHP plant work with syngas. Thus, a total of five selected gaseous fuels were analysed.

Brief characteristics of each of these fuels together with volume fractions and calculated calorific value are presented below. The calorific values of each of the gaseous fuels discussed below were calculated in the EBSILON $^{\circledR}$ Professional 13 program automatically after entering presented volume fractions of individual components of the gas mixture, and these values were adopted for further analysis. 


\subsection{Biogas}

Biogas is the mixture of gases produced by the breakdown of organic matter in the absence of oxygen. It can be produced from raw materials such as agricultural waste, manure, municipal waste, plant material, sewage, green waste or food waste. Biogas is primarily methane and carbon dioxide and may have small amounts of hydrogen sulfide, moisture and siloxanes [9].

Because of low calorific value and flame speed biogas is found to be worse fuel than the conventional fuels, therefore it is often enriched by hydrogen or methane.

For our analysis we have decided to use biogas from work [10]. The composition of this biogas is presented in Table 2.

Table 2. Composition of biogas used for analysis [10].

\begin{tabular}{|l|c|c|}
\hline \multicolumn{1}{|c|}{ Component } & Value & Unit \\
\hline $\mathrm{CH}_{4}$ & 49.777 & Volume \% \\
\hline $\mathrm{CO}_{2}$ & 43.535 & Volume $\%$ \\
\hline $\mathrm{CO}$ & 1.197 & Volume \% \\
\hline $\mathrm{H}_{2}$ & 0.489 & Volume \% \\
\hline $\mathrm{N}_{2}$ & 4.759 & Volume \% \\
\hline $\mathrm{O}_{2}$ & 0.243 & Volume \% \\
\hline Calorific value & 13977.464 & $\mathrm{~kJ} / \mathrm{kg}$ \\
\hline
\end{tabular}

\subsection{Blast furnace gas}

Blast furnace gas is a by-product of blast furnaces that is generated when the iron ore is reduced with coke to metallic iron. It has a very low heating value because it consists of about 60 percent nitrogen and $18-20 \%$ carbon dioxide, which are not flammable. The rest is mostly carbon monoxide, which has a fairly low heating value already and some hydrogen [11].

It is commonly used as a fuel within the steel works, but it can be used in boilers and power plants equipped to burn it. It may be combined with natural gas or coke oven gas before combustion or a flame support with richer gas or oil is provided to sustain combustion. Because of the high concentration of carbon monoxide blast furnace gas is hazardous.

Composition of blast furnace gas used in our analysis is presented in Table 3 and the source of the volume fractions values is paper [12].

Table 3. Composition of blast furnace gas used for analysis [12].

\begin{tabular}{|l|c|c|}
\hline \multicolumn{1}{|c|}{ Component } & Value & Unit \\
\hline $\mathrm{CO}_{2}$ & 20.09 & Volume $\%$ \\
\hline $\mathrm{CO}$ & 23.74 & Volume $\%$ \\
\hline $\mathrm{H}_{2}$ & 2.05 & Volume $\%$ \\
\hline $\mathrm{N}_{2}$ & 53.41 & Volume $\%$ \\
\hline $\mathrm{O}_{2}$ & 0.71 & Volume $\%$ \\
\hline Calorific value & 2348.173 & $\mathrm{~kJ} / \mathrm{kg}$ \\
\hline
\end{tabular}

\subsection{Coke gas}

Coal gas is a flammable gaseous fuel made from coal. It is a by-product of the coking process and it is produced when coal is heated strongly in the absence of air. Coal gas contains a variety of calorific gases including hydrogen, carbon monoxide, methane, ethylene and volatile hydrocarbons together with small quantities of non-calorific gases such as $\mathrm{CO}_{2}$ and $\mathrm{N}_{2}$ [13].

Because of high amount of $\mathrm{CH}_{4}$ and $\mathrm{H}_{2}$ coke gas has a higher calorific value than other alternative gas fuels. Due to this fact, coal gas can be supplied to the user via a piped distribution system in the same way as natural gas.

The coke gas used in our analysis is produced in steel plant placed in Krakow, Poland [14]. Composition of this gas is presented in Table 4 .

Table 4. Composition of coke gas used for analysis [14].

\begin{tabular}{|l|c|c|}
\hline \multicolumn{1}{|c|}{ Component } & Value & Unit \\
\hline $\mathrm{CH}_{4}$ & 23.7 & Volume \% \\
\hline $\mathrm{CO}_{2}$ & 2.6 & Volume $\%$ \\
\hline $\mathrm{CO}$ & 6.6 & Volume $\%$ \\
\hline $\mathrm{H}_{2}$ & 57.3 & Volume $\%$ \\
\hline $\mathrm{N}_{2}$ & 7.2 & Volume $\%$ \\
\hline $\mathrm{O}_{2}$ & 0.2 & Volume $\%$ \\
\hline $\mathrm{C}_{\mathrm{n}} \mathrm{H}_{\mathrm{m}}$ & 2.4 & Volume $\%$ \\
\hline Calorific value & 35498.049 & $\mathrm{~kJ} / \mathrm{kg}$ \\
\hline
\end{tabular}

\subsection{Syngas}

Syngas is a fuel gas mixture consisting primarily of hydrogen, carbon monoxide, and very often some carbon dioxide. Syngas is usually a product of coal gasification and the main application is electricity generation. Syngas is combustible and can be used as a fuel of internal combustion engines. Syngas has less than half the energy density of natural gas [15].

Syngas can be produced from many sources, including natural gas, coal, biomass, or virtually any hydrocarbon feedstock, by reaction with steam (steam reforming), carbon dioxide (dry reforming) or oxygen (partial oxidation).

Due to the fact, that in Poland we still have large coal reserves, which can be used in electricity and heat production, we have decided to use in our analysis only syngas from two most popular coal gasification processes. It means from Koppers-Totzek gasification system and Lurgi gasification system.

\subsubsection{Koppers-Totzek gasification}

The Koppers-Totzek gas generator is based on a turbulent flux. Coal is supplied to direct-flow reactors together with gasifying agents - steam and oxygen. The reactor is at elevated pressure and temperature. In contrast to processes with a compact bed, the use of turbulent flux permits the gasification of different types of coal and produces gas at high temperature; the gas is free of tars and phenol [15]. 
Composition of syngas obtained from KoppersTotzek gasification process used in the analysis is presented in Table 5.

Table 5. Composition of syngas Koppers-Totzek used for analysis [15].

\begin{tabular}{|l|c|c|}
\hline \multicolumn{1}{|c|}{ Component } & Value & Unit \\
\hline $\mathrm{CO}_{2}$ & 65.2 & Volume \% \\
\hline $\mathrm{CO}$ & 0.8 & Volume \% \\
\hline $\mathrm{H}_{2}$ & 25.5 & Volume \% \\
\hline $\mathrm{N}_{2}$ & 8.2 & Volume \% \\
\hline $\mathrm{H}_{2} \mathrm{~S}$ & 0.3 & Volume \% \\
\hline Calorific value & 11507.881 & $\mathrm{~kJ} / \mathrm{kg}$ \\
\hline
\end{tabular}

\subsubsection{Lurgi gasification}

One of the commonest and oldest-established technologies is gasification in a steady bed by the Lurgi method. Gasification in a dense fuel bed at atmospheric pressure extracts practically all of the valuable components. Gasification of a dense bed of coal pieces at elevated pressure is also employed [15].

Composition of syngas obtained from Lurgi gasification process used in the analysis is presented in Table 6.

Table 6. Composition of syngas Lurgi used for analysis [15].

\begin{tabular}{|l|c|c|}
\hline \multicolumn{1}{|c|}{ Component } & Value & Unit \\
\hline $\mathrm{CH}_{4}$ & 7.6 & Volume $\%$ \\
\hline $\mathrm{CO}_{2}$ & 2.6 & Volume $\%$ \\
\hline $\mathrm{CO}$ & 60.6 & Volume \% \\
\hline $\mathrm{H}_{2}$ & 27.8 & Volume $\%$ \\
\hline $\mathrm{N}_{2}$ & 1.0 & Volume $\%$ \\
\hline $\mathrm{C}_{\mathrm{n}} \mathrm{H}_{\mathrm{m}}$ & 0.4 & Volume $\%$ \\
\hline Calorific value & 15245.344 & $\mathrm{~kJ} / \mathrm{kg}$ \\
\hline
\end{tabular}

\section{Thermodynamic analysis of a Velox- type CHP plant for considered gas fuels}

Figures 2, 3 and 4 and Table 7 shows a comparison of the calculated, selected thermodynamic parameters for the nominal load of the analysed Velox-type CHP plant working with the gaseous fuels presented above.

Fig. 2 shows a comparison of cycle efficiency with a breakdown into the efficiency of electricity and heat generation. The total cycle efficiency, depending on the fuel used, remains basically unchanged and fluctuates slightly within $77 \%$. Larger differences can be seen in the efficiency of generating electricity or heat alone. It can be seen here that the cycle fired with blast furnace gas demonstrate the highest efficiency of electricity generation. This efficiency is $23.8 \%$, compared to approximately $20.5 \%$ for other cases. However, the heat generation efficiency is reduced for this case. For a cycle fired with blast furnace gas it is $53.8 \%$, compared to approximately $56 \%$ for other cases.

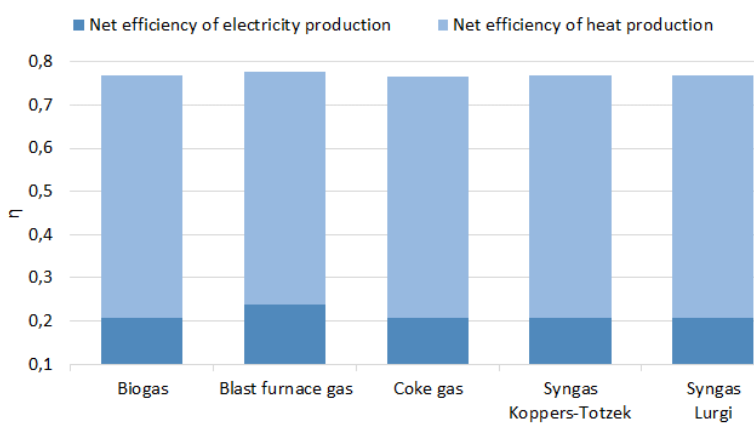

Fig. 2. Efficiency for nominal load of the thermal cycle fired with gas fuels under consideration.

For the cycle fired with blast furnace gas compared to other cases, higher production of both electricity and heat was noticed (see also Fig. 6). At the same operating parameters, such as pressure and temperature of steam and exhaust gases, for each case, these differences are obviously associated with both exhaust gas and steam mass flow rates. As can be seen in Fig. 3 primarily the exhaust gas mass flow rate for a cycle fired with blast furnace gas is much larger compared to other cases, hence more exhaust gas energy can be converted into useful work here.

However, the production of larger amounts of exhaust gas is associated with largest demand for fuel, the more that blast furnace gas has the lowest calorific value of all fuels analysed here. Additionally, in Fig. 3 we can see that for the nominal load of the analysed Velox-type CHP plant, the least fuel should be supplied to the cycle fired with coke gas $(0.0018 \mathrm{~kg} / \mathrm{s})$ and this is not much more than for previously conducted analyses for natural gas [6]. The next in order are cases fired with fuels: syngas Lurgi $(0.0042 \mathrm{~kg} / \mathrm{s})$, biogas $(0.0047 \mathrm{~kg} / \mathrm{s})$, syngas Koppers-Totzek $(0.0057 \mathrm{~kg} / \mathrm{s})$ and at the very end the already mentioned blast furnace gas $(0.0376 \mathrm{~kg} / \mathrm{s})$. Considering the calorific values of individual considered gaseous fuels, this order should have been expected.

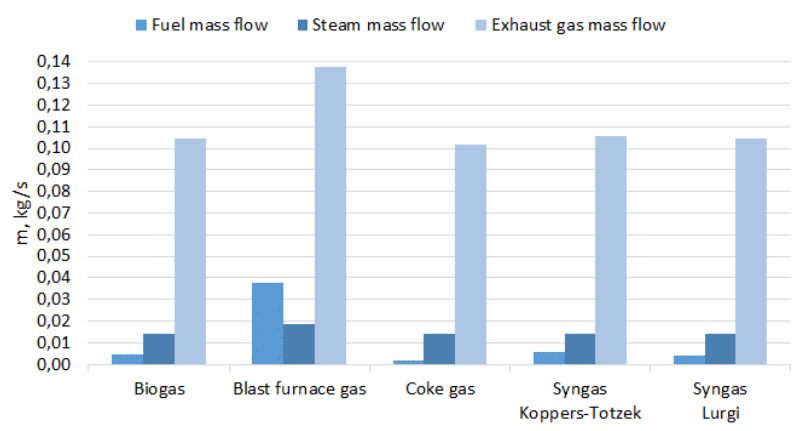

Fig. 3. M ass flow rates for fuel, steam and exhaust gas for nominal load of the thermal cycle fired with gas fuels under consideration.

It should also be noted that the larger mass flow rates of exhaust gases or steam, the heat exchange surfaces also increase (Fig. 4 and Table 7). In Fig. 4 and Table 7 we can also see that the largest heat exchange area should be provided for the heat exchanger in the heating water circuit for the cycle fired with blast furnace gas. This cycle, compared to other cases, would also need the 
largest heat exchange areas in the economizer, evaporator and superheater. Other cases have heat exchange surfaces very similar, therefore a change of fuel for the Velox-type CHP plant under consideration would not require major structural changes, except for the use of blast furnace gas as a fuel.

Table 7. Surface area of the heat exchangers (kA parameter) of the thermal cycle fired with various gas fuels (nominal load).

\begin{tabular}{|c|c|c|c|c|c|c|}
\hline Parameter & Biogas & $\begin{array}{c}\text { Blast } \\
\text { furnace gas }\end{array}$ & $\begin{array}{c}\text { Coke } \\
\text { gas }\end{array}$ & $\begin{array}{c}\text { Syngas } \\
\text { Koppers-Totzek }\end{array}$ & $\begin{array}{l}\text { Syngas } \\
\text { Lurgi }\end{array}$ & Unit \\
\hline Economizer & 0.241 & 0.322 & 0.232 & 0.239 & 0.236 & $\mathrm{~kW} / \mathrm{K}$ \\
\hline Evaporator & 0.131 & 0.168 & 0.127 & 0.130 & 0.128 & $\mathrm{~kW} / \mathrm{K}$ \\
\hline Superheater & 0.129 & 0.168 & 0.126 & 0.128 & 0.127 & $\mathrm{~kW} / \mathrm{K}$ \\
\hline Heat exchanger in the heating water circuit & 1.503 & 1.951 & 1.462 & 1.493 & 1.478 & $\mathrm{~kW} / \mathrm{K}$ \\
\hline Sum & 2.003 & 2.610 & 1.947 & 1.990 & 1.969 & $\mathrm{~kW} / \mathrm{K}$ \\
\hline
\end{tabular}

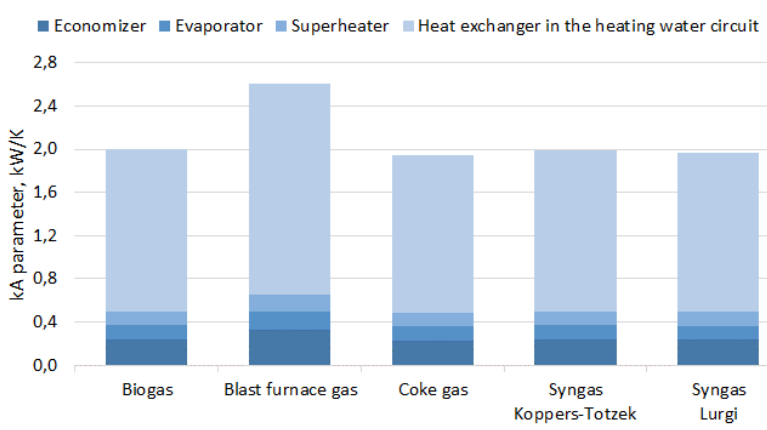

Fig. 4. Surface area of the heat exchangers (kA parameter) for nominal load of the thermal cycle fired with gas fuels under consideration.

Figures 5-9 presents the operational characteristics of Velox-type CHP plant working with the gaseous fuels under consideration for various loads. From the analysis of these figures, it can be concluded that for each fuel the operating range of the considered cases is very similar. The flexibility of the Velox-type CHP plant fired with various gaseous fuels is again confirmed, as it was for natural gas in earlier analysis presented in [6].

In addition, in Fig. 6 it can be also seen a slightly larger operating range for the cycle fired with blast furnace gas, compared to other cases, as well as greater production of both electric power and thermal power, and slightly greater efficiency, which has already been shown for nominal load and is associated with energy flow for this case.

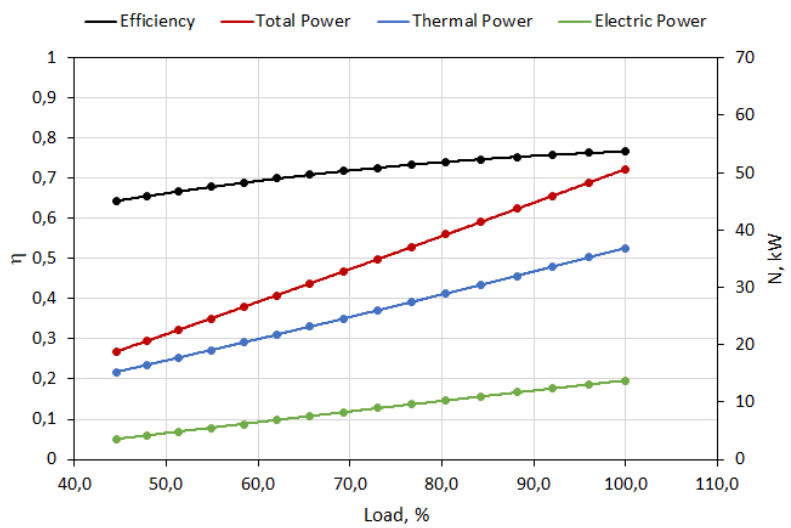

Fig. 5. Operational characteristics of the V elox-type CHP plant fired with biogas for different loads.

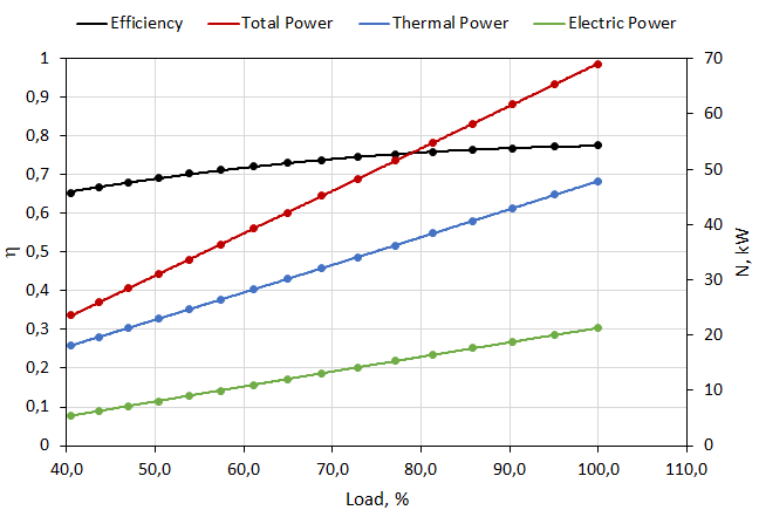

Fig. 6. Operational characteristics of the V elox-type CHP plant fired with blast furnace gas for different loads.

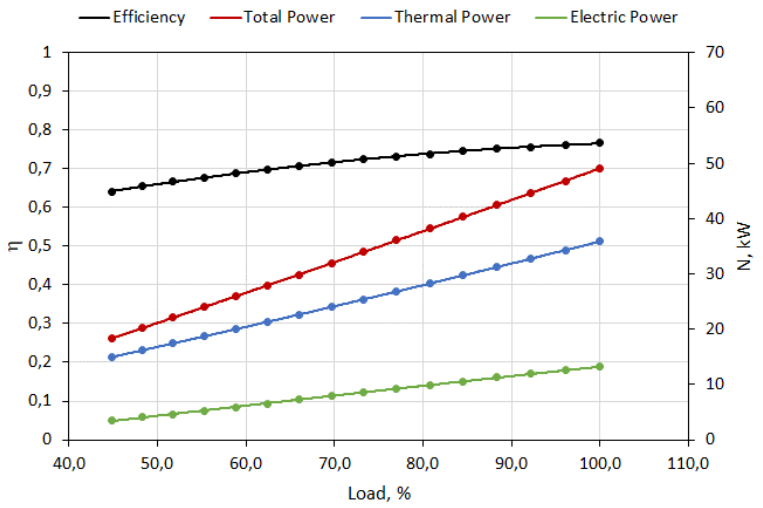

Fig. 7. Operational characteristics of the V elox-type CHP plant fired with coke gas for different loads.

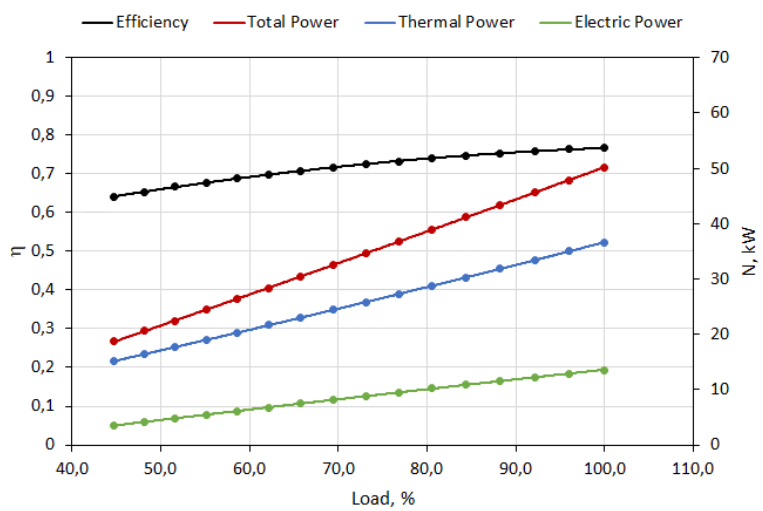

Fig. 8. Operational characteristics of the V elox-type CHP plant fired with syngas K oppers-Totzek for different loads. 


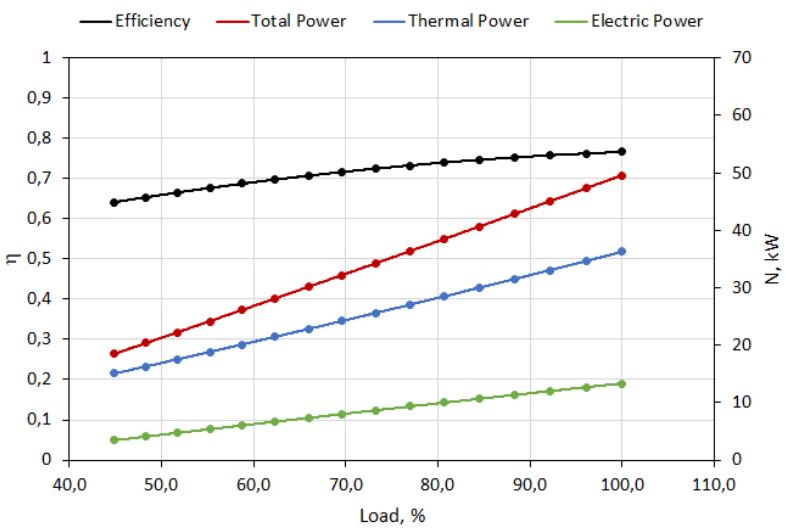

Fig. 9. O perational characteristics of the V elox-type CHP plant fired with syngas L urgi for different loads.

\section{Conclusions}

Obtained results from the analysis of the work of Veloxtype CHP plant fired with alternative gaseous fuels led to the following conclusions:

- the cycle under consideration can work successfully with any of the proposed unconventional gaseous fuels,

- for the same operating parameters assumed for each case, the largest demand for fuel is shown for the cycle fired with blast furnace gas,

- $\quad$ also the cycle fired with blast furnace gas would be the largest CHP plant due to the largest heat exchange areas required for each of the heat exchanger used,

- the cycles fired with biogas, coke gas and both types of syngas could work with any of these fuels without major structural changes.

Thus, Velox-type CHP plant creates great opportunities for distributed generation of electricity and heat with the power output of the order of a few megawatts. This cycle can be adapted at a low cost to work with each of the alternative gas fuels under consideration.

The presented work was supported by the Silesian University of Technology within Statutory Research Funds.

\section{References}

1. Gaffert G.A., Steam Power Stations, McGraw-Hill Book Company, New York and London, (1940).

2. The Brown Boveri Review Issued by Brown, Boveri \& Company, Baden (Switzerland), Vol. XXXI, Nos. $1 / 2,(1944)$.

3. Kotowicz J., Elektrownie gazowo-parowe [Gassteam power plants], KAPRINT, Lublin, (2008).

4. Dykas S., Kotowicz J., Smołka K., Niekomercyjna instalacja parowej mini-siłowni kondensacyjnej w Politechnice Śląskiej [Non-Commercial Installation of a Mini Steam Power Plant in the Silesian University of Technology], Rynek Energii, No. 4(95), pp. 47-52, (2011).

5. Smołka K., Dykas S., Rulik S., A comparative analysis of the performance of a steam-gas system of a Velox-type cycle and a gas-steam power station using a waste-heat boiler, Proceedings of $4^{\text {rd }}$ International Conference on Contemporary Problems of Thermal Engineering, (2016).

6. Smołka K., Dykas S., The performance of a steamgas power unit of a Velox-type cycle, Journal of Power Technologies, Vol. 97, No 5, pp. 343-348, (2017).

7. Bartela Ł., Optymalizacja termodynamiczna oraz ekonomiczna pracy elektrociepłowni gazowoparowej [Thermodynamic and economic optimization of the gas-steam power plant], $\mathrm{PhD}$ dissertation, Gliwice, (2009).

8. Kotowicz J., Bartela Ł., The influence of economic parameters on the optimal values of the design variables of a combined cycle plant, Energy, Vol. 35 Issue 2, pp. 911-919, (2010).

9. Wellinger A., Murphy J.D., Baxter D., The Biogas Handbook: Science, Production and Applications, Woodhead Publishing, (2013).

10. Kruczek G., Experimental and numerical investigation of combustion process of conventional and alternative fuels in Internal Combustion Engine, $\mathrm{PhD}$ dissertation, Gliwice, (2018).

11. Liu Y., Wang Y., Wang H., Li P., Experimental Investigations on Combustion Characteristics of the Blast Furnace Gas, Proceedings of $3^{\text {rd }}$ International Conference on Bioinformatics and Biomedical Engineering, (2009).

12. Bhattacharya A., Muthusamy S., Static Heat Energy Balance Mathematical Model for an Iron Blast Furnace, International Journal of Mineral Processing and Extractive Metallurgy, Vol. 2, Issue 5, pp. 57-67, (2017).

13. Razzaq R., Li C., Zhang S., Coke oven gas: Availability, properties, purification, and utilization in China, Fuel, Vol. 113, pp. 287-299, (2013).

14. Bieda B., Grzesik K., Sala D., Gaweł B., Life cycle inventory processes of the integrated steel plant (ISP) in Krakow, Poland - coke production, a case study, The International Journal of Life Cycle Assesment, Vol. 20, Issue 8, pp. 1089-1101, (2015).

15. Podgorodetskii G.S., Yusfin Yu.S., Sazhin A.Yu., Gorbunov V.B., Polulyakh L.A., Production of Generator Gas from Solid Fuels, Steel in Translation, Vol. 45, Issue 6, pp. 395-402, (2015). 